\title{
Block Depleted
}

National Cancer Institute

\section{Source}

National Cancer Institute. Block Depleted. NCI Thesaurus. Code C131122.

An indication that a sample block has been depleted by testing. 